\title{
Stakeholder Knowledge and Behavioral Integration in Boards of Social Enterprises: a Team Production Approach
}

\begin{abstract}
The social entrepreneurship literature increasingly acknowledges that the board of directors is of major importance in dealing with the specific tensions that social enterprises face. Using a team production perspective, we argue that the extent to which board members possess relevant knowledge about stakeholder groups, enhances the engagement of the board in counseling and decision-making (i.e. board service performance). Furthermore, we expect that such engagement is positively related to organizational performance, which is multifaceted, in line with the hybrid nature of social enterprises. Finally, we investigate the contingency factors under which board stakeholder knowledge relates to board service performance and subsequent organizational performance. Particularly, we claim that such knowledge is especially relevant in cases of strong behavioral integration among board members. Using a sample of Flemish social enterprises, we find that board stakeholder knowledge is positively related to board service performance. This relationship is further moderated by strong board behavioral integration, which is strengthening the relationship in cases of high stakeholder knowledge, but has a mitigating effect in cases of low stakeholder knowledge. Finally, while board service performance is positively related to the social goal of hiring disadvantaged people, it is not significantly related to financial performance.
\end{abstract}

\section{Keywords:}

Governance, social enterprises, board of directors, team production theory 


\section{INTRODUCTION}

Social enterprises are described as hybrid organizations as they pursue a dual mission of creating social value as well as being financially sustainable (Doherty et al., 2014; Pache and Santos, 2013). As such, they combine the creation of social value, associated with the non-profit sector, with traditional business approaches, associated with for-profit organizations (Wilson and Post, 2013). Specifically, social enterprises aim at fulfilling 'wicked problems', such as social exclusion or poverty (Dacin et al., 2010; Mair et al., 2012; Santos, 2012). The combining and balancing of social and financial goals in decision-making is described as a major internal challenge in social enterprises (Battilana and Lee, 2014). Particularly, some authors have commented on the erosion of social goals in favor of financial performance ((Doherty et al., 2014), whereas others have documented the reverse situation in which the overemphasis of social goals and the neglect of financial goals lead to business failure (Cornforth, 2014; Tracey et al., 2011). While a number of causes for the origination of such goal imbalance have been articulated in the literature (Cornforth, 2014; Jones, 2007), a high level of dependence on a single or a limited number of stakeholders in the external environment is frequently mentioned as one of the core reasons for its occurrence (Bennett and Savani, 2011). Indeed, social enterprises often lack a dominant stakeholder and face the challenge of aligning the interests of a wide range of stakeholders such as the beneficiaries of their social mission, their customers, funders and governments (Ebrahim et al., 2014; Pache and Santos, 2010). In such circumstances, stakeholders may have conflicting expectations and demands, and social enterprises may have to decide which demands they prioritize on (Ebrahim et al., 2014).

Corporate governance mechanisms in general and the board of directors in particular are considered vital in dealing with these specific challenges in social enterprises (Battilana and Lee, 2014; 
Ebrahim et al., 2014; Mair et al., 2015; Pache and Santos, 2013; Spear et al., 2009). Boards in social enterprises can contribute in a number of ways. First, boards may serve as a connection between the social enterprise and its stakeholders in the external environment (Ebrahim et al., 2014). Moreover, through their understanding of the interests and expectations of external stakeholders, board members may play a major role in securing stakeholder support as well as in identifying risks and opportunities in the external environment (Doherty et al., 2014; Ebrahim et al., 2014). This will help the board to balance potential tensions between the social and financial goals in decision-making (Cornforth, 2014; Pestoff and Hulgård, 2015). This is because boards do not only engage in a control role, but are also active in their service role, through which they engage in advice giving and strategic decision making (Hillman and Dalziel, 2003; Hillman et al., 2000; Minichilli et al., 2009). Accordingly, it is through the engagement in their service role (which we refer to, in line with Minichilli et al. (2009) and Crucke and Knockaert (2016), as 'board service performance') that boards contribute to the safeguarding of the social and financial mission and performance of social enterprises.

Therefore, in this paper, using a team production perspective, we specifically study the relationship between stakeholder knowledge in the board and board service performance, and the extent to which this board service performance is positively related to organizational performance. In doing so, we also investigate the circumstances under which these relationships become weaker or stronger. Particularly, we argue that boards will be particularly contributing in case they actively work together as a team and use their knowledge on external stakeholder groups. As such, in considering the relationship between board stakeholder knowledge and board service performance, we study the influence of behavioral integration. Behavioral integration is a concept introduced by Hambrick (1994), measuring the tendency of groups, such as boards, to engage in more teamlike behavior (Li and Hambrick, 2005). 
In studying the relationship between board stakeholder knowledge, board service performance and organizational performance alongside its contingency factors, we contribute to the social entrepreneurship and corporate governance literatures in a number of ways. First, we contribute to the social entrepreneurship literature by providing an understanding into how social enterprises internally deal with the specific tensions related to their hybrid nature (Pache and Santos, 2010). Importantly, while the board of directors is expected to be an important mechanism in dealing with such tensions, the governance mechanism has so far received surprisingly little attention in social entrepreneurship research (Ebrahim et al., 2014). As such, this paper responds to calls to study the governance function in social enterprises (Doherty et al., 2014; Mair et al., 2015). We further add to the social enterprise literature by studying financial and social performance in conjunction. While there is a consensus that social enterprises should be evaluated by considering financial and non-financial performance simultaneously (Austin et al., 2006; Smith et al., 2013), there is a dearth of research that does so (Battilana et al., 2015; Coombes et al., 2011; Liu et al., 2014). Second, we contribute to the corporate governance literature. While board service performance has recently received considerable interest, studies have so far mainly focused on understanding the antecedents of board service performance (Knockaert et al., 2015; Minichilli et al., 2009). Only few studies have examined the relationship between board service performance and organizational performance. Importantly, studies that focused on the latter relationship have typically focused on financial performance (Minichilli et al., 2012; Westphal, 1999; Zattoni et al., 2015). As such, we aim at contributing to this literature by studying the relationship between board service performance and organizational performance as a multidimensional construct.

The structure of the paper is as follows. In the next section, we present our theoretical framework building on team production theory. Subsequently, we describe the research method, including the research setting, data collection and the measures used, followed by the presentation of our results. 
The article concludes with the discussion of main conclusions and contributions, as well as the limitations and directions for future research.

\section{THEORETICAL BACKGROUND AND HYPOTHESES}

\section{Board stakeholder knowledge and board service performance: a team production perspective}

Team production theory (Blair and Stout, 1999; Kaufman and Englander, 2005) is particularly relevant for our research objectives as it focuses on stakeholder groups and is instrumental in understanding the mediating role of the board of directors. First, team production theory can be considered as a reaction to agency theory and its logic of shareholder primacy (Aguilera et al., 2015). According to team production theory, an organization embodies several stakeholder groups, including shareholders and non-shareholder groups such as employees, creditors, local governments, suppliers and consumers, who collectively make contributions in order to make an organization successful (Lan and Heracleous, 2010). This is certainly the case for social enterprises, which are particularly exposed to diverging expectations by different stakeholder groups (Battilana and Dorado, 2010; Pache and Santos, 2010). Second, in team production theory, the board of directors is assigned the role of 'mediating hierarch' and central decision making body of the organization (Heracleous and Lan, 2012). From this perspective, the main function of the board is no longer the monitoring function aimed at reducing agency costs. Instead, the board has to balance potentially competing stakeholder expectations and interests (Aguilera et al., 2015). A main challenge of the board is to take decisions in the best interest of the organization while meeting the needs of various stakeholders, such that stakeholder groups are satisfied and are willing to continue contributing to the organization (Mahoney and Kor, 2015). This approach to the board's role is 
also particularly relevant for social enterprises in which the balancing of the often competing demands of several stakeholder groups is crucial. Indeed, in cases of diverging stakeholder expectations, multi-stakeholder governance is considered a good practice (Cornforth and Spear, 2010; Spear et al., 2009). Particularly, Kaufman and Englander (2005) argue that, in order to fulfill its mediating role properly, the board should reflect stakeholder groups. In other words, the board must have board members, who have knowledge about one or several stakeholder groups and their interests. Such knowledge will help board members in identifying risks and opportunities in the external environment, which is important for adequate advice giving and decision-making in consideration of the needs and expectations of different stakeholder groups (Doherty et al., 2014; Ebrahim et al., 2014; Gabrielsson et al., 2007; Huybrechts et al., 2014). Based on these arguments, we argue that boards of social enterprises with higher levels of stakeholder knowledge will be better able to engage in their service role, and thus reach higher board service performance. Subsequently, we propose the following hypothesis:

Hypothesis 1. Board stakeholder knowledge is positively related to board service performance.

\section{Board service performance and organizational performance}

When boards engage in their service role, they are expected to contribute to the maximization of value creation (Finkelstein and Mooney, 2003; Forbes and Milliken, 1999; Minichilli et al., 2012). Indeed, it has been argued that, as board members provide qualified advice and participate in decision-making, they enhance organizational performance (Hillman and Dalziel, 2003; Hillman et al., 2009). This is in line with team production theory, indicating that boards contribute collectively to the organization in order to make it successful (Lan and Heracleous, 2010). At the 
same time, only a limited number of studies have examined the relationship between board service performance and organizational performance, and those that did, focused exclusively on financial performance (Minichilli et al., 2012; Westphal, 1999; Zattoni et al., 2015). However, as performance is a multi-dimensional construct, and diverse dimensions deserve attention, particularly in a social entrepreneurship context, we need to consider social performance alongside financial performance (Austin et al., 2006; Battilana et al., 2015). This is because several scholars have argued that boards may play an important role in overseeing the creation of social value alongside the achievement of financial sustainability (Doherty et al., 2014; Ebrahim et al., 2014). Through their engagement in the service role, boards can balance the social and financial goals in giving advice and engaging in strategic decision-making. As such, in line with team production theory, and considering the multi-dimensional nature of performance, we argue that there will be a positive relationship between board service performance and social and financial performance. In studying social performance, we then consider two primary social goals of social enterprises, namely hiring disadvantaged people and engaging in community responsibilities (Cornforth and Spear, 2010; Spear and Bidet, 2005). By consequence, we formulate the following hypotheses:

Hypothesis 2a. Board service performance is positively related to hiring disadvantaged people.

Hypothesis 2b. Board service performance is positively related to engaging in community responsibilities.

Hypothesis 2c. Board service performance is positively related to financial performance.

\section{Behavioral integration as a contingency factor}

The corporate governance literature emphasizes the importance of behavioral aspects and internal processes within the board (Filatotchev and Boyd, 2009; Hambrick et al., 2008; Huse et al., 2011). 
Along the same lines, team production theory emphasizes the importance of cooperation in the board; it considers the board as a cooperative team in which performance increases as board members interact with each other (Kaufman and Englander, 2005). More specifically, the theory argues that internal processes are crucial in order to actively use the knowledge and expertise of board members. Each board member brings relevant knowledge to the board. However, there is no single board member who has, on his or her own, all the information and knowledge necessary to take adequate decisions. It is through the interaction between the board members that boards become more effective in terms of counseling and decision-making (Gabrielsson et al., 2007; Machold et al., 2011). This is in line with the concept of 'behavioral integration' defined as 'the degree to which mutual and collective action exists within the group' and assessing the teamlike behavior of groups, such as boards ( $\mathrm{Li}$ and Hambrick, 2005). By consequence, behaviorally integrated boards, are characterized by a higher quality and quantity of information exchange (Lubatkin et al., 2006). As such, behavioral integration enables boards to better use available knowledge (Machold et al., 2011) and enhances counseling and decision making within the board (Li and Hambrick, 2005). While bringing stakeholder knowledge to the firm is important, we argue that this is particularly the case when behavioral integration allows this knowledge to be shared and applied. Building on these arguments, we contend that behavioral integration in the board will enhance the positive effect of board stakeholder knowledge on board service performance. We offer the following hypothesis:

Hypothesis 3. The positive relationship between board stakeholder knowledge and board service performance is strengthened by higher levels of board behavioral integration. 
Our conceptual model is presented in Figure 1.

Insert Figure 1 about here

\section{METHODOLOGY}

\section{Research setting and sample}

Although entrepreneurs and organizations aiming for social value creation have always existed, studies on social entrepreneurship have only recently emerged (Bacq and Janssen, 2011). Furthermore, the conceptualization of social entrepreneurship and its development has widely differed between the US and Europe, with very few connections until the years 2004-2005 (Defourny and Nyssens, 2010). In Europe, social enterprises mainly emerged because of the persistence of high rates of unemployment during the 1980s and the increasing exclusion of vulnerable groups from the labor market and society. Instead of relying only on passive labor market policies, authorities have started to encourage and develop active labor policies (Defourny and Nyssens, 2010). By consequence, social enterprises were set up to reintegrate people in society by offering them a job, while simultaneously providing job training and social support (Battilana et al., 2015; Pache and Santos, 2010). As a consequence 'Work integration social enterprises' (WISEs) are the dominant type of social enterprises in Europe (Defourny and Nyssens, 2008). This is also the case in Belgium, the country in which this study is conducted. However, there is a growing awareness, also among policy makers, that entrepreneurship with social aims goes beyond work integration. Indeed, more organizations offering entrepreneurial, innovative responses to unsolved social needs have recently emerged. While the goals of these organizations are different 
from those of WISEs, they are often still concerned about the integration of vulnerable people. As such, also these social enterprises frequently provide jobs with the aim of work integration (Siqueira et al., 2018).

Our sample consists of social enterprises in Flanders, one of the regions of Belgium. The data were collected as part of a research project with support of the Flemish government, which provided the names and contact information of Flemish social enterprises. In line with the above discussion, the following organizations were included as social enterprises: (1) sheltered workshops and social workshops, established with the main purpose of reintegrating job seekers who face difficulties to find a job in the regular job market because of physical, social or psychological problems, mainly operating in packaging, assembly, gardening, recycling, and printing (Battilana et al., 2015), (2) work experience enterprises and work care initiatives, offering a job to long-term unemployed people and mainly active in health and social care or the cultural sector (Van Opstal et al., 2009), (3) work integration enterprises employing long-term unemployed jobseekers and integrating them into their regular staff (Van Opstal et al., 2009) and (4) cooperatives: member-based democratic organizations (Spear, 2004).

\section{Data collection}

In order to reach our research objectives, we combine primary data obtained from an online questionnaire as well as secondary data available in the public database Belfirst.

First, a survey was administered, comprising questions on general company information, board dynamics and board tasks, as well as on the functioning and (non-financial) performance of the social enterprises. The questionnaire was distributed in 2014 to the CEOs of all 812 Flemish social enterprises, using a web-based tool (Qualtrics). After a period of intensive follow-up (through e- 
mail and telephone), a total of 199 CEOs completed the survey, yielding a response rate of $25 \%$. Second, the survey data were matched with the secondary data obtained from Belfirst, which is relatively straightforward as each enterprise has a unique firm identifier (i.e. the enterprise's Value Added Tax code). Belfirst contains information on annual accounting information of all Belgian enterprises. The Belfirst database is compiled by Bureau van Dijk (BvD)—one of Europe's leading electronic publishers of business information. When the financial statements are filed with the National Bank of Belgium, they are processed and checked and subsequently made available to the public. BvD collects these data to compile the Belfirst database. Because of missing financial data in Belfirst, our final dataset comprises 182 social enterprises.

\section{Measures}

\section{Dependent and mediator variables}

Board service performance. Board service performance is measured using 8 items of the scale developed by Minichilli et al. (2009) and is incorporating the advice giving and strategic participation of the board service role (Hillman and Dalziel, 2003; Huse, 2005). Respondents were asked to indicate on a seven-point Likert scale (ranging from 1: strongly disagree to 7: strongly agree) to what extent the board fulfills its service role. Specifically, we asked respondents to indicate the degree to agreement with the following items: The board (1) provides advice on management issues; (2) provides advice on financial issues; (3) provides advice on technical issues; (4) provides advice on market issues; (5) provides advice on legal issues; (6) is involved in promoting strategic initiatives; (7) is involved in taking strategic decisions; and (8) is involved in participating in the implementation phase of long-term strategic decision-making.

Hiring disadvantaged people. The degree to which social enterprises engage in hiring disadvantaged people is measured using five items based on Crucke and Decramer (2016). Hiring 
disadvantaged people was then assessed using a seven-point Likert scale through which respondents indicated their agreement with the following statements: (1: strongly disagree; 7 : strongly agree): (1) Our organization actively hires immigrants, (2) Our organization actively hires low skilled people, (3) Our organization actively hires elderly people, (4) Our organization actively hires long term unemployed people and (5) Our organization actively hires disabled people.

Community responsibilities. To measure the degree to which social enterprises incorporate community responsibilities, we used the scale developed by Crucke and Decramer (2016). Community responsibilities was assessed using a seven-point Likert scale through which respondents indicated their agreement with the following statements (1: strongly disagree; 7: strongly agree): (1) Our organization informs the local community by organizing presentations, company visits,..., (2) Our organization offers traineeships to students, (3) Our organization offers products and/or services to vulnerable people, (4) Our organization addresses unsolved societal problems, (5) Our organization pursues partnerships with governments, for profit organizations, social economy organizations, labor agencies and other community organizations.

Financial performance. In line with previous research studying social enterprises (Stevens et al., 2015) and the impact of boards on organizational performance (Payne et al., 2009; Zattoni et al., 2015), we used return on assets (ROA) to assess financial performance. Specifically, we measured financial performance by calculating the mean of ROA 2014 and ROA 2015. As the measure is prone to outliers, we winsorized this variable in order to convert it outliers into its 5th or 95th percentiles (Miller and Le Breton-Miller, 2011). Information for the calculation of this variable was obtained from the public database Belfirst. 


\section{Independent variables}

Board stakeholder knowledge. In order to measure this independent variable, we used the measure developed by Kim and Cannella (2008), focusing on the knowledge of board members about several stakeholder groups and industries. As we perform our study in the context of social enterprises, we added one item (item 4 below) to the measure, in order to also capture the knowledge of the board on important social organizations. Specifically, the respondents were asked to indicate on an seven-point Likert scale (ranging from 1: strongly disagree to 7: strongly agree), the degree to which they agreed with the following statements: (1) The board appoints lead outside directors, (2) The board has members who know important financing institutions, (3) The board has members who know important customers of the organization, (4) The board has members who know important social (nonprofit) organizations, (5) The board has members who know important suppliers of the organization (6) The board consists of members with diverse industry/ sector backgrounds.

Behavioral integration. Behavioral integration is measured using the measure of Li and Hambrick (2005). The respondents were asked to indicate on an seven-point Likert scale (ranging from 1: strongly disagree to 7: strongly agree), the degree to which they agreed with the following statements: (1) All the directors have a voice in major decisions affecting the organization, (2) Communications among directors can be best described as open and fluid, (3) When major decisions are made affecting the organization, the directors collectively exchange their points of view, (4) The directors of the organization frequently share their experience and expertise. 


\section{Control variables}

We further added control variables at board and firm level that may affect board service performance (Minichilli et al., 2012; Zona and Zattoni, 2007). At board level, we control for the frequency of board meetings, as the frequency of board meetings is likely to affect board service performance (Knockaert and Ucbasaran, 2013). Further, as each board member may bring different linkages and resources to the board, also board size is expected to influence board service performance and is thus controlled for (Knockaert and Ucbasaran, 2013; Minichilli et al., 2009). At the organizational level, we controlled for age and size of the organization as the need for advice and establishing legitimacy by board members may vary between young and old, and small and large organizations (Knockaert et al., 2015; Minichilli et al., 2012). Furthermore, age and size are typically considered important drivers of organizational performance (Wiklund and Shepherd, 2005), which also holds for social enterprises (Liu et al., 2014; Weerawardena and Mort, 2012). The size of the organization is operationalized as the number of employees, obtained from the public database Belfirst. The organization's age is obtained by using the date of incorporation obtained from Belfirst.

\section{RESULTS}

\section{Analytical approach}

To test our theoretical model, we applied Partial Least Squares Structural Equation Modeling (PLSSEM; also referred to as PLS path modeling), using the SmartPLS 3 package (Hair et al., 2017). The following features make PLS-SEM particularly appropriate for our study. First, PLS-SEM allows to model latent variables and to simultaneously assess both measurement and structural models. This implies that PLS-SEM enables to test the validity of the constructs used and to assess the paths between the latent constructs. Second, PLS-SEM imposes minimal requirements on 
sample size and residual distributions. While covariance-based SEM recommends sample sizes ranging from 200 to 800 (Bandalos, 1997; Marsh et al., 1998), PLS-SEM has the advantage that it achieves robustness and statistical power in the case of smaller sample sizes (Sarstedt et al., 2014). Moreover, PLS-SEM allows the use of models with many constructs and indicators (items), while covariance-based SEM recommends that the number of indicators should be limited in the case of small sample sizes, which is particularly challenging in research using lengthy ordinal scales (Yang et al., 2010).

We follow the commonly used two-stage procedure as proposed by Hair et al. (2017). In a first step, the PLS-SEM results of the measurement model are assessed to evaluate the reliability, the convergent validity and the discriminant validity of the individual constructs. In a second step, the PLS-SEM results of the structural model are assessed to test the hypothesized relationships between the variables. As suggested by Hair et al. (2017), we first run the model without moderator to test for hypothesis 1 . Subsequently, we run the model adding the moderator in order to assess hypothesis 3 .

\section{Measurement model, descriptive statistics and correlations}

In a first step, we assess the reliability and validity of the individual constructs by evaluating the reflective measurement model, presented in Table I. We apply the following general expected thresholds to assess, respectively, indicator reliability, internal consistency reliability and convergent validity: (1) indicator's outer loadings should preferably be higher than 0.7 , (2) composite reliability (CR) and Cronbach's alpha should be higher than 0.6, (3) Average Variance Extracted (AVE) should be higher than 0.5. 
To assess the indicator reliability, we first study the size and the significance of the outer loadings of the items. Two items (item 6 of 'Board stakeholder knowledge' and item 5 of 'Hiring disadvantaged people') are eliminated from their construct as their outer loading is very low $(<0.40)$ and not statistically significant (Hair et al., 2017). Consequently, we study the items with outer loadings between 0.40 and 0.70 . In order to increase the value of the AVE and CR above the threshold value, we eliminated two more items (item 4 of 'Board stakeholder knowledge' and item 2 of 'Community responsibilities'). Table 1 gives an overview of the outer loadings of the items, the composite reliability (CR) and the average variance extracted (AVE) for each construct. Table I indicates that the constructs have acceptable internal consistency reliability as all CR scores are higher than 0.7. The fact that all constructs have an AVE exceeding the threshold of 0.5 indicates convergent validity.

\section{Insert Table I about here}

We finally assess the discriminant validity of the constructs by studying the Heterotrait-Monotrait Ratio (HTMT). All HTMT values are lower than the threshold of 0.85 and neither of the confidence intervals includes the value 1, supporting discriminant validity.

Table II provides the means, standard deviations and correlations for all variables.

Insert Table II about here

None of the correlations exceeds 0.8 , indicating that multicollinearity is not likely to affect our results (Gujarati and Porter, 2008). 


\section{Structural Model}

The structural model is used to test for the hypothesized relationships between the latent variables. We assess the strength and significance of the path coefficients, applying a bootstrapping procedure with 5,000 bootstrap samples. Table III gives an overview of the results of the structural model.

Insert Table III about here

We first consider Model 1 (the full model without the moderator). The path coefficients show that board stakeholder knowledge has a significant positive effect $(0.433, \mathrm{p}<0.001)$ on board service performance, supporting Hypothesis 1 . In addition, board service performance $(0.155, \mathrm{p}<0.05)$ is significantly positively related to 'hiring disadvantage people', supporting hypothesis 2a. Hypotheses $2 \mathrm{~b}$ and $2 \mathrm{c}$ are not supported as we find a non-statistically significant coefficient. Subsequently, we assess model 2 with behavioral integration as a moderating variable. In line with Aguinis et al. (2011), we use the 10\%-significance level as an appropriate cut-off point for assessing interaction effects. Our results support hypothesis 3 as we find that there is a significant, positive moderating effect of behavioral integration $(0.174, \mathrm{p}<0.10)$.

Some of the control variables in Models 1 and 2 also point to interesting additional relationships. Particularly, the number of board meetings and organization age are positively related to board service performance. Organizational age further has a negative effect on hiring disadvantage people.

In order to interpret the significant interaction between board stakeholder knowledge and behavioral integration in explaining board service performance, we visualize the interaction in Figure 2 using standardized data. The figure demonstrates that the slope of board stakeholder 
knowledge is steeper for organizations with higher levels of behavioral integration. The figure also indicates that increasing levels of behavioral integration only strengthen board service performance if the standardized value of board stakeholder knowledge is higher than 0.25 . A standardized value of 0.25 corresponds to a value on the Likert scale of the mean added with $0.25^{*}$ standard deviation, or $4.34\left(=4.02+0.25^{*} 1.28=4.34\right)$. If board stakeholder knowledge is lower, higher levels of behavioral integration even mitigate board service performance. This finding indicates that it is of little relevance to establish a board with high levels of behavioral integration, if that board does not possess knowledge on the organization's stakeholders.

Insert Figure 2 about here

\section{DISCUSSION AND CONCLUSION}

In the social entrepreneurship literature, a consensus is emerging that the board of directors is of major importance to deal with the specific tensions social enterprises, as hybrid organizations, face (Doherty et al., 2014). Boards have the ultimate responsibility to balance the social and financial goals in decision-making to ensure financial viability as well as the achievement of the social mission (Cornforth, 2014). Social enterprises lack a dominant stakeholder, instead they are accountable to multiple principal stakeholders with diverging interest, such as the beneficiaries of the social mission, clients and governments (Ebrahim et al., 2014). Social enterprises are expected to be better able to deal with the diverging expectations of stakeholders when relevant knowledge about the stakeholder groups is available within the board (Huybrechts et al., 2014). Moreover, 
taking in consideration stakeholder expectations is in line with the democratic and participatory values that typify social enterprises (Pestoff and Hulgård, 2015).

In this paper, we took a team production perspective to study how stakeholder knowledge is instrumental in helping boards to fulfill their service role, subsequently influencing organizational performance. Furthermore, as it is commonly accepted that boards function better if they act as teams (Finkelstein and Mooney, 2003), we also study board behavioral integration, referring to the teamlike behavior of boards.

The results of our study of boards in Flemish social enterprises indicate that board stakeholder knowledge is positively related to board service performance. Our study further assessed whether board service performance is related to organizational outcomes. In doing so, we followed the recommendation to study both financial as well as social performance in social enterprises (Austin et al., 2006). The results of our study indicate that board service performance is positively related to the social goal of hiring disadvantaged people. However, we did not find support for a positive relationship between board service performance and financial performance. This is line with the results of the study by Coombes et al. (2011), who studied the impact of behavioral aspects of social enterprise boards on entrepreneurial orientation and subsequently on financial and social performance. A possible explanation can be found in the paper of Pache and Santos (2013), studying how social enterprises deal internally with the conflicting demands they are exposed to. The authors discuss one particular pattern of managing internal tensions, which they refer to as 'Trojan horse'. It means that internal actors related to stakeholder groups representing commercial goals, choose to enact practices sustaining the social goals to compensate for the lack of legitimacy in the social enterprise context because of their affiliation with commercially oriented organizations. Although the scope in the study of Pache and Santos (2013) is different as they study the affiliations and connections of founders of social enterprises, we believe that this mechanism 
may possibly also explain the extent to which board member behavior in the service role relates to financial performance. Furthermore, our study indicates that behavioral integration in the board is an important factor in strengthening board service performance, particularly if the board has sufficient knowledge on the organization's stakeholders.

Our study contributes to the literature in a number of ways. First, it contributes to the social entrepreneurship literature, which has largely neglected to provide insights into the governance function in social enterprises (Mair et al., 2015), and how this governance function can help social enterprises to deal with the challenges they are confronted with. Indeed, whereas social enterprise scholars have advocated the integration of stakeholder expectations in social enterprise governance in line with the democratic and participatory values social enterprise subscribe (Huybrechts et al., 2014; Pestoff and Hulgård, 2015), we currently have few insights into how such integration can benefit the social enterprise. Particularly, our study points to the importance of boards possessing relevant knowledge on stakeholder groups, resulting in a stronger engagement by the board in its service role. As we further show, such engagement is particularly important in order for social enterprises to reach the social goal of hiring disadvantaged people. Second, through analyzing which board characteristics affect board service performance and subsequent organizational performance under which conditions, our study is of interest to both the social entrepreneurship and corporate governance literatures. While most studies have either focused on the link between board characteristics and board service performance, or on the relationship between board service performance and financial performance, to our knowledge, only few studies have provided a more holistic picture by uniting these elements (Zattoni et al., 2015). In doing so, our study also acknowledges that performance is a multi-dimensional construct, and unites social and financial performance in one research design. Our results also emphasize the importance of board behavioral 
integration for board service performance, and as such contribute to calls in the corporate governance literature to gain deeper insights into the role of board cohesiveness (Finkelstein and Mooney, 2003; Huse et al., 2011).

Our study also has implications for practitioners, such as CEOs of social enterprises and their stakeholders. First, it reveals that social enterprises can expect to have boards that engage more actively in their service role, if they possess strong knowledge on the different stakeholder groups. This is particularly the case if these boards also have strong levels of behavioral integration. In accordance with Lubatkin et al. (2006), denoting the role of CEOs in strengthening behavioral integration within top management teams, we point to the pivotal role of the board chair in selecting, evaluating and motivating board members in order to reach behavioral integration. Second, practitioners may benefit from understanding the relationship between a stronger engagement by the board in its service role and organizational performance, in which our results point to a strong relationship between this engagement and one of the social goals, namely the hiring of disadvantaged people.

Our study also has some limitations, which have implications for the interpretations of our findings and for future research. First, our study uses a cross-sectional design. While we built our arguments and the directions of these arguments in line with team production theory, we are unable to make strong claims on the direction of the relationships. Longitudinal studies may provide additional insights into how board composition contributes to board performance and subsequent organizational performance (Machold and Farquhar, 2013). Additionally, qualitative studies may contribute in gaining additional insights in how stakeholder knowledge shapes board dynamics and board decisions (Sundaramurthy et al., 2014). Second, our study was executed in a particular context, namely that of Flemish social enterprises. While we do not have reasons to believe that our choice of context is likely to affect our results, future research could fruitfully study the 
relationship between board stakeholder knowledge, board service performance and organizational performance in other contexts, where other definitions of social entrepreneurship apply (e.g. the US), or where corporate governance laws differ. Third, while our study specifically points to the importance of board behavioral integration for board service performance, it does not study the antecedents of such behavioral integration. Future research could as such purposefully study the relationship between board member characteristics (e.g. human capital), board characteristics (e.g. board cohesion), board evaluation and development practices (Gill et al., 2005; Kiel and Nicholson, 2005), board chair characteristics (e.g. leadership and communication style) (Harrison and Murray, 2012), and interaction patterns in building teamlike behavior within boards.

Despite these limitations, this study contributed by shedding light on the understudied corporate governance function in social enterprises, hereby particularly focusing on the relationship between board characteristics, board service performance and subsequent organizational performance. 


\section{REFERENCES}

Aguilera, R. V., Desender, K., Bednar, M. K. , \& Lee, J. H. (2015). Connecting the Dots: Bringing External Corporate Governance into the Corporate Governance Puzzle. Academy of Management Annals, 9(1), 483-573.

Aguinis, H., Dalton, D. R., Bosco, F. A., Pierce, C. A. , \& Dalton, C. M. (2011). Meta-analytic choices and judgment calls: Implications for theory building and testing, obtained effect sizes, and scholarly impact. Journal of Management, 37(1), 5-38.

Austin, J., Stevenson, H. , \& Wei-Skillern, J. (2006). Social and Commercial Entrepreneurship: Same, Different, or Both? Entrepreneurship: Theory \& Practice, 30(1-22.

Bacq, S. , \& Janssen, F. (2011). The multiple faces of social entrepreneurship: A review of definitional issues based on geographical and thematic criteria. Entrepreneurship \& Regional Development, 23(5-6), 373-403.

Bandalos, D. L. (1997). Assessing sources of error in structural equation models: The effects of sample size, reliability, and model misspecification. Structural Equation Modeling: A Multidisciplinary Journal, 4(3), 177-192.

Battilana, J. , \& Dorado, S. (2010). Building sustainable hybrid organizations: the case of commercial microfinance organizations. Academy of Management Journal, 53(6), 1419-1440.

Battilana, J. , \& Lee, M. (2014). Advancing Research on Hybrid Organizing - Insights from the Study of Social Enterprises. Academy of Management Annals, 8(1), 397-441.

Battilana, J., Sengul, M., Pache, A.-C. , \& Model, J. (2015). Harnessing Productive Tensions in Hybrid Organizations: The Case of Work Integration Social Enterprises. Academy of Management Journal, 58(6), 1658-1685. 
Bennett, R. , \& Savani, S. (2011). Surviving mission drift: How charities can turn dependence on government contract funding to their own advantage. Nonprofit Management and Leadership, $22(2), 217-231$.

Blair, M. M. , \& Stout, L. A. (1999). A team production theory of corporate law. Virginia Law Review, 247328.

Coombes, S. M. T., Morris, M. H., Allen, J. A. , \& Webb, J. W. (2011). Behavioural Orientations of Non-Profit Boards as a Factor in Entrepreneurial Performance: Does Governance Matter? Journal of Management Studies, 48(4), 829-856.

Cornforth, C. (2014). Understanding and combating mission drift in social enterprises. Social Enterprise Journal, 10(1), 3.

Cornforth, C. , \& Spear, R. (2010). 'The governance of hybrid organizations'. In D. Billis (Ed.), Hybrid organizations and the third sector: challenges for practice, theory and policy. Basingstoke, UK: Palgrave, 70-89.

Crucke, S. , \& Decramer, A. (2016). The Development of a Measurement Instrument for the Organizational Performance of Social Enterprises. Sustainability, 8(2).

Crucke, S. , \& Knockaert, M. (2016). When Stakeholder Representation Leads to Faultlines. A Study of Board Service Performance in Social Enterprises. Journal of Management Studies, 53(5), 768-793.

Dacin, P. A., Dacin, M. T. , \& Matear, M. (2010). Social Entrepreneurship: Why We Don't Need a New Theory and How We Move Forward From Here. Academy of Management Perspectives, 24(3), 37-57.

Defourny, J. , \& Nyssens, M. (2008). Social enterprise in Europe: recent trends and developments. Social Enterprise Journal, 4(3), 202-228.

Defourny, J. , \& Nyssens, M. (2010). Conceptions of Social Enterprise and Social Entrepreneurship in Europe and the United States: Convergences and Divergences. Journal of Social Entrepreneurship, 1(1), 32-53. 
Doherty, B., Haugh, H. , \& Lyon, F. (2014). Social Enterprises as Hybrid Organizations: A Review and Research Agenda. International Journal of Management Reviews, 16(417-436.

Ebrahim, A., Battilana, J. , \& Mair, J. (2014). The governance of social enterprises: Mission drift and accountability challenges in hybrid organizations. Research in Organizational Behavior, 34(0), 81100.

Filatotchev, I. , \& Boyd, B. K. (2009). Taking Stock of Corporate Governance Research While Looking to the Future. Corporate Governance-an International Review, 17(3), 257-265.

Finkelstein, S. , \& Mooney, A. C. (2003). Not the usual suspects: How to use board process to make boards better. Academy of Management Executive, 17(2), 101-113.

Forbes, D. P. , \& Milliken, F. J. (1999). Cognition and Corporate Governance: Understanding boards of directors as strategic decision-making groups. Academy of Management Review, 24(3), 489-505.

Gabrielsson, J., Huse, M. , \& Minichilli, A. (2007). Understanding the leadership role of the board chairperson through a team production approach. International journal of leadership studies, 3(1), 21-39.

Gill, M., Flynn, R. J. , \& Reissing, E. (2005). The governance self-assessment checklist: An instrument for assessing board effectiveness. Nonprofit Management and Leadership, 15(3), 271-294.

Gujarati, D. , \& Porter, D. (2008). Basic Econometrics. 5th Edition edition. Europe: McGraw-Hill.

Hair, J. F., Hult, G. T. M., Ringle, C. M. , \& Sarstedt, M. (2017). A primer on partial least squares structural equation modeling (PLS-SEM). Second edition. Los Angeles: Sage.

Hambrick, D. (1994). Top management groups: A conceptual integration and reconsideration of the team label. In BM Staw \& LL Cummings (Eds.), Research in organizational behavior, Vol. 16: 171-214. Greenwich, CT: JAI: CT: JAI Press.

Hambrick, D. C., Werder, A. v. , \& Zajac, E. J. (2008). New Directions in Corporate Governance Research. Organization Science, 19(3), 381-385. 
Harrison, Y. D. , \& Murray, V. (2012). Perspectives on the leadership of chairs of nonprofit organization boards of directors: A grounded theory mixed-method study. Nonprofit Management \& Leadership, 22(4), 411-437.

Heracleous, L. , \& Lan, L. L. (2012). Agency Theory, Institutional Sensitivity, and Inductive Reasoning: Towards a Legal Perspective. Journal of Management Studies, 49(1), 223-239.

Hillman, A., J. , \& Dalziel, T. (2003). Boards of Directors and Firm Performance: Integrating Agency and Resource Dependence Perspectives. The Academy of Management Review, 28(3), 383-396.

Hillman, A. J., Cannella, A. A. , \& Paetzold, R. L. (2000). The resource dependence role of corporate directors: strategic adaptation of board composition in response to environmental change. Journal of Management Studies, 37(2), 235-255.

Hillman, A. J., Withers, M. C. , \& Collins, B. J. (2009). Resource Dependence Theory: A Review. Journal of Management, 35(6), 1404-1427.

Huse, M. (2005). Accountability and Creating Accountability: a Framework for Exploring Behavioural Perspectives of Corporate Governance. British Journal of Management, 16(65-79.

Huse, M., Hoskisson, R., Zattoni, A. , \& Vigano, R. (2011). New Perspectives on Board Research: Changing the Research Agenda. Journal of Management and Governance, 15(1), 5-28.

Huybrechts, B., Mertens, S. , \& Rijpens, J. (2014). 'Explaining stakeholder involvement in social enterprise governance through resources and legitimacy'. In J. Defourny, L. Hulgard \& V. Pestoff (Eds.), Social Enterprise and the Third Sector: Changing European Landscapes in a Comparative Perspective. Londen \& New York: Routledge.

Jones, M. B. (2007). The Multiple Sources of Mission Drift. Nonprofit and Voluntary Sector Quarterly, 36(2), 299-307.

Kaufman, A. , \& Englander, E. (2005). A team production model of corporate governance. Academy of Management Executive, 19(3), 9-22. 
Kiel, G. C. , \& Nicholson, G. J. (2005). Evaluating Boards and Directors. Corporate Governance: An International Review, 13(5), 613-631.

Kim, Y. , \& Cannella, A. A. (2008). Toward a Social Capital Theory of Director Selection. Corporate Governance: An International Review, 16(4), 282-293.

Knockaert, M., Bjornali, E. S. , \& Erikson, T. (2015). Joining forces: Top management team and board chair characteristics as antecedents of board service involvement. Journal of Business Venturing, 30(3), 420-435.

Knockaert, M. , \& Ucbasaran, D. (2013). The Service Role of Outside Boards in High Tech Start-ups: A Resource Dependency Perspective. British Journal of Management, 24(1), 69-84.

Lan, L. L. , \& Heracleous, L. (2010). Rethinking agency theory: the view from law Academy of Management Review, 35(2), 294-314.

Li, J. , \& Hambrick, D. C. (2005). Factional groups: a new vantage on demographic faultlines, conflict, and disintegration in work teams. Academy of Management Journal, 48(5), 794-813.

Liu, G., Takeda, S. , \& Ko, W.-W. (2014). Strategic Orientation and Social Enterprise Performance. Nonprofit and Voluntary Sector Quarterly, 43(3), 480-501.

Lubatkin, M. H., Simsek, Z., Ling, Y. , \& Veiga, J. F. (2006). Ambidexterity and performance in small-to medium-sized firms: The pivotal role of top management team behavioral integration. Journal of Management, 32(5), 646-672.

Machold, S. , \& Farquhar, S. (2013). Board Task Evolution: A Longitudinal Field Study in the UK. Corporate Governance: An International Review, 21(2), 147-164.

Machold, S., Huse, M., Minichilli, A. , \& Nordqvist, M. (2011). Board Leadership and Strategy Involvement in Small Firms: A Team Production Approach. Corporate Governance: An International Review, 19(4), 368-383. 
Mahoney, J. T. , \& Kor, Y. Y. (2015). Advancing the human capital perspective on value creation by joining capabilities and governance approaches Academy of Management Perspectives, 29(3), 296-308.

Mair, J., Battilana, J. , \& Cardenas, J. (2012). Organizing for Society: A Typology of Social Entrepreneuring Models. Journal of Business Ethics, 111(3), 353-373.

Mair, J., Mayer, J. , \& Lutz, E. (2015). Navigating Institutional Plurality: Organizational Governance in Hybrid Organizations. Organization Studies, 36(6), 713-739.

Marsh, H. W., Hau, K.-T., Balla, J. R. , \& Grayson, D. (1998). Is More Ever Too Much? The Number of Indicators per Factor in Confirmatory Factor Analysis. Multivariate Behavioral Research, 33(2), 181-220.

Miller, D. , \& Le Breton-Miller, I. (2011). Governance, Social Identity, and Entrepreneurial Orientation in Closely Held Public Companies. Entrepreneurship Theory and Practice, 35(5), 1051-1076.

Minichilli, A., Zattoni, A., Nielsen, S. , \& Huse, M. (2012). Board task performance: An exploration of microand macro-level determinants of board effectiveness. Journal of Organizational Behavior, 33(2), 193-215.

Minichilli, A., Zattoni, A. , \& Zona, F. (2009). Making Boards Effective: An Empirical Examination of Board Task Performance. British Journal of Management, 20(1), 55-74.

Pache, A.-C. , \& Santos, F. (2010). When worlds collide: the internal dynamics of organizational responses to conflicting institutional demands. Academy of Management Review, 35(3), 455-476.

Pache, A.-C. , \& Santos, F. (2013). Inside the hybrid organization: selective coupling as response to conflicting institutional logics. Academy of Management Journal, 56(4), 972-1001.

Payne, G. T., Benson, G. S. , \& Finegold, D. L. (2009). Corporate Board Attributes, Team Effectiveness and Financial Performance. Journal of Management Studies, 46(4), 704-731.

Pestoff, V. , \& Hulgård, L. (2015). Participatory Governance in Social Enterprise. VOLUNTAS: International Journal of Voluntary and Nonprofit Organizations, 1-18. 
Santos, F. M. (2012). A Positive Theory of Social Entrepreneurship. Journal of Business Ethics, 111(3), 335351.

Sarstedt, M., Ringle, C. M. , \& Hair, J. F. (2014). PLS-SEM: Looking Back and Moving Forward. Long Range Planning, 47(3), 132-137.

Siqueira, A. C. O., Guenster, N., Vanacker, T. , \& Crucke, S. (2018). A longitudinal comparison of capital structure between young for-profit social and commercial enterprises. Journal of Business Venturing. In Press.

Smith, W. K., Gonin, M. , \& Besharov, M. L. (2013). Managing Social-Business Tensions: A Review and Research Agenda for Social Enterprise. Business Ethics Quarterly, 23(3), 407-442.

Spear, R. (2004). Governance in Democratic Member-Based Organisations. Annals of Public \& Cooperative Economics, 75(33-59.

Spear, R. , \& Bidet, E. (2005). Social enterprise for work integration in 12 european countries: a descriptive analysis*. Annals of Public and Cooperative Economics, 76(2), 195-231.

Spear, R., Cornforth, C. , \& Aiken, M. (2009). The governance challenges of social enterprises: evidence from a UK empirical study. Annals of Public \& Cooperative Economics, 80(2), 247-273.

Stevens, R., Moray, N., Bruneel, J. , \& Clarysse, B. (2015). Attention allocation to multiple goals: The case of for-profit social enterprises. Strategic management journal, 36(7), 1006-1016.

Sundaramurthy, C., Pukthuanthong, K. , \& Kor, Y. (2014). Positive and negative synergies between the CEO's and the corporate board's human and social capital: A study of biotechnology firms. Strategic management journal, 35(6), 845-868.

Tracey, P., Phillips, N. , \& Jarvis, O. (2011). Bridging Institutional Entrepreneurship and the Creation of New Organizational Forms: A Multilevel Model. Organization Science, 22(1), 60-80.

Van Opstal, W., Deraedt, E. , \& Gijselinckx, C. (2009). Monitoring profile shifts and differences among WISEs in Flanders. Social Enterprise Journal, 5(3), 229-258. 
Weerawardena, J. , \& Mort, G. S. (2012). Competitive Strategy in Socially Entrepreneurial Nonprofit Organizations: Innovation and Differentiation. Journal of Public Policy \& Marketing, 31(1), 91-101. Westphal, J. D. (1999). Collaboration in the boardroom: behavioral and performance consequences of CEO-board social ties. Academy of Management Journal, 42(1), 7-24.

Wiklund, J. , \& Shepherd, D. (2005). Entrepreneurial orientation and small business performance: a configurational approach. Journal of Business Venturing, 20(1), 71-91.

Wilson, F. , \& Post, J. E. (2013). Business models for people, planet (\& profits): exploring the phenomena of social business, a market-based approach to social value creation. Small Business Economics, 40(3), 715-737.

Yang, C., Nay, S. , \& Hoyle, R. H. (2010). Three Approaches to Using Lengthy Ordinal Scales in Structural Equation Models: Parceling, Latent Scoring, and Shortening Scales. Applied Psychological Measurement, 34(2), 122-142.

Zattoni, A., Gnan, L. , \& Huse, M. (2015). Does Family Involvement Influence Firm Performance? Exploring the Mediating Effects of Board Processes and Tasks. Journal of Management, 41(4), 1214-1243.

Zona, F. , \& Zattoni, A. (2007). Beyond the Black Box of Demography: board processes and task effectiveness within Italian firms. Corporate Governance: An International Review, 15(5), 852-864. 
FIGURE 1

Conceptual model

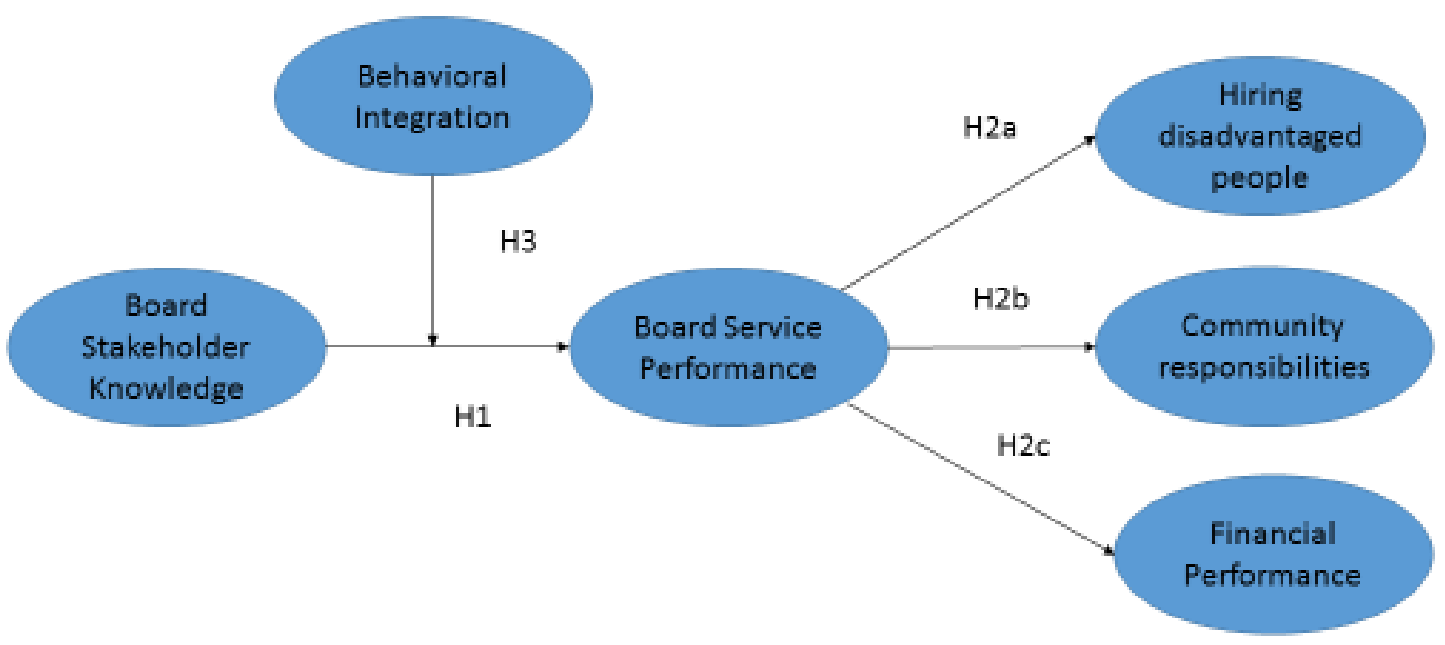




\section{TABLE I}

Reflective measurement model

\begin{tabular}{|c|c|c|c|c|c|}
\hline & & Loading & AVE & CR & Cronbach's $\alpha$ \\
\hline \multirow[t]{8}{*}{ Board Service Performance } & Item 1 & 0.790 & 0,623 & 0,929 & 0,912 \\
\hline & Item 2 & 0.842 & & & \\
\hline & Item 3 & 0.797 & & & \\
\hline & Item 4 & 0.769 & & & \\
\hline & Item 5 & 0.813 & & & \\
\hline & Item 6 & 0.729 & & & \\
\hline & Item 7 & 0.757 & & & \\
\hline & Item 8 & 0.795 & & & \\
\hline \multirow[t]{4}{*}{ Board Stakeholder Knowledge } & Item 1 & 0.764 & 0,502 & 0,801 & 0,698 \\
\hline & Item 2 & 0.643 & & & \\
\hline & Item 3 & 0.727 & & & \\
\hline & Item 4 & 0.693 & & & \\
\hline \multirow[t]{4}{*}{ Hiring disadvantaged people } & Item 1 & 0.790 & 0,673 & 0,891 & 0,829 \\
\hline & Item 2 & 0.862 & & & \\
\hline & Item 3 & 0.712 & & & \\
\hline & Item 4 & 0.882 & & & \\
\hline \multirow[t]{4}{*}{ Community responsibilities } & Item 1 & 0.694 & 0,566 & 0,838 & 0,745 \\
\hline & Item 2 & 0.679 & & & \\
\hline & Item 3 & 0.864 & & & \\
\hline & Item 4 & 0.736 & & & \\
\hline \multirow[t]{4}{*}{ Behavioral Integration } & Item 1 & 0.787 & 0,779 & 0,934 & 0,899 \\
\hline & Item 2 & 0.909 & & & \\
\hline & Item 3 & 0.891 & & & \\
\hline & Item 4 & 0.893 & & & \\
\hline
\end{tabular}




\section{TABLE II}

Mean, Standard Deviations and Correlations

\begin{tabular}{|c|c|c|c|c|c|c|c|c|c|c|c|c|}
\hline & Mean & SD & 1. & 2. & 3. & 4. & 5. & 6. & 7. & 8. & 9. & 10. \\
\hline 1. Frequency of Board Meetings & 6.05 & 3.06 & 1 & & & & & & & & & \\
\hline 2. Board Size & 8.47 & 4.55 & $0.12^{\dagger}$ & 1 & & & & & & & & \\
\hline 3. Firm Age & 26 & 17 & 0,08 & $0.24 * * *$ & 1 & & & & & & & \\
\hline 4. Firm Size & 181 & 521 & 0.04 & 0.12 & $0.24 * * *$ & 1 & & & & & & \\
\hline 5. Board Stakeholder Knowledge & 4.02 & 1.28 & -0.10 & $-0.24 * * *$ & -0.06 & -0.04 & 1 & & & & & \\
\hline 6. Behavioral integration & 5.74 & 0.97 & $0.23 * * *$ & $-0.19 * *$ & 0.09 & -0.00 & 0.06 & 1 & & & & \\
\hline 7. Board Service Performance & 4.50 & 1.29 & $0.18 * *$ & $-0.19 * *$ & 0.00 & 0.02 & $0.39 * * *$ & $0.52 * * *$ & 1 & & & \\
\hline 8. Hiring disadvantaged people & 4.88 & 1.51 & -0.02 & $-0.12 \dagger$ & $-0.20 * *$ & -0.05 & 0.11 & $0.16^{*}$ & .012 & 1 & & \\
\hline 9. Community responsibilities & 4.87 & 1.32 & $0.27 * * *$ & $0.28 * * *$ & 0.01 & -0.05 & -0.03 & $0.12 \dagger$ & -0.02 & $0.15^{*}$ & 1 & \\
\hline 10. Financial performance & 0.03 & 0.06 & -0.09 & -0.06 & -0.05 & -0.02 & $0.13 \dagger$ & 0.01 & -0.04 & 0.13 & -0.02 & 1 \\
\hline
\end{tabular}

\section{Note.}

$\dagger p<.10, * p<.05, * * p<.01, * * * p<.001$

$n=182$ 


\section{TABLE III}

\section{Results Structural model}

\begin{tabular}{|c|c|c|c|c|c|c|c|c|}
\hline & \multicolumn{4}{|c|}{ Model 1 (without moderator) } & \multicolumn{4}{|c|}{ Model 2 (with moderator) } \\
\hline & \multirow[b]{2}{*}{$\begin{array}{c}\text { Path } \\
\text { coefficiënt }\end{array}$} & \multirow[b]{2}{*}{$p$ value } & \multicolumn{2}{|c|}{$\begin{array}{c}95 \% \\
\text { bootstrapped } \\
\text { intervals }\end{array}$} & \multirow[b]{2}{*}{$\begin{array}{c}\text { Path } \\
\text { coefficiënt }\end{array}$} & \multirow[b]{2}{*}{$p$ value } & \multicolumn{2}{|c|}{$\begin{array}{c}95 \% \\
\text { bootstrapped } \\
\text { intervals }\end{array}$} \\
\hline & & & $2.5 \%$ & $97.5 \%$ & & & $2.5 \%$ & $97.5 \%$ \\
\hline \multicolumn{9}{|l|}{ Control variables } \\
\hline boardmeetings $->$ board service performance & 0.238 & 0.000 & 0.105 & 0.358 & 0.226 & 0.000 & 0.095 & 0.344 \\
\hline boardsize $->$ board service performance & -0.121 & 0.057 & -0.245 & 0.005 & -0.101 & 0.118 & -0.228 & 0.025 \\
\hline size $->$ board service performance & -0.099 & 0.119 & -0.223 & 0.026 & -0.092 & 0.140 & -0.211 & 0.033 \\
\hline size -> community responsibilities & 0.017 & 0.862 & -0.186 & 0.190 & 0.043 & 0.696 & -0.203 & 0.238 \\
\hline size -> hiring disadvantaged people & 0.022 & 0.783 & -0.135 & 0.184 & 0.022 & 0.779 & -0.133 & 0.175 \\
\hline size -> financial performance & 0.074 & 0.323 & -0.075 & 0.224 & 0.074 & 0.333 & -0.075 & 0.227 \\
\hline Age $->$ board service performance & 0.133 & 0.057 & -0.003 & 0.270 & 0.141 & 0.045 & 0.007 & 0.279 \\
\hline Age -> community responsibilities & 0.111 & 0.233 & -0.087 & 0.276 & 0.120 & 0.199 & -0.088 & 0.281 \\
\hline Age -> hiring disadvantaged people & -0.176 & 0.028 & -0.332 & -0.019 & -0.176 & 0.028 & -0.333 & -0.015 \\
\hline Age -> financial performance & 0.140 & 0.094 & -0.027 & 0.300 & 0.140 & 0.097 & -0.031 & 0.302 \\
\hline \multicolumn{9}{|l|}{ Main variables } \\
\hline behavioral Integration -> board service performance & & & & & -0.042 & 0.606 & -0.185 & 0.123 \\
\hline board stakeholder knowledge -> board service performance & 0.433 & 0.000 & 0.322 & 0.555 & 0.434 & 0.000 & 0.322 & 0.552 \\
\hline moderating Effect $->$ board service performance & & & & & 0.174 & 0.057 & 0.044 & 0.377 \\
\hline board service performance $->$ community responsibilities & -0.097 & 0.381 & -0.281 & 0.145 & -0.052 & 0.725 & -0.290 & 0.241 \\
\hline board service performance -> hiring disadvantaged people & 0.154 & 0.046 & 0.001 & 0.309 & 0.155 & 0.044 & 0.003 & 0.308 \\
\hline board service performance $->$ financial performance & 0.050 & 0.515 & -0.096 & 0.202 & 0.049 & 0.524 & -0.101 & 0.200 \\
\hline
\end{tabular}

Note: $n=182$. 
FIGURE 2

Moderating effect of behavioral integration on the relationship between board stakeholder knowledge and board service performance

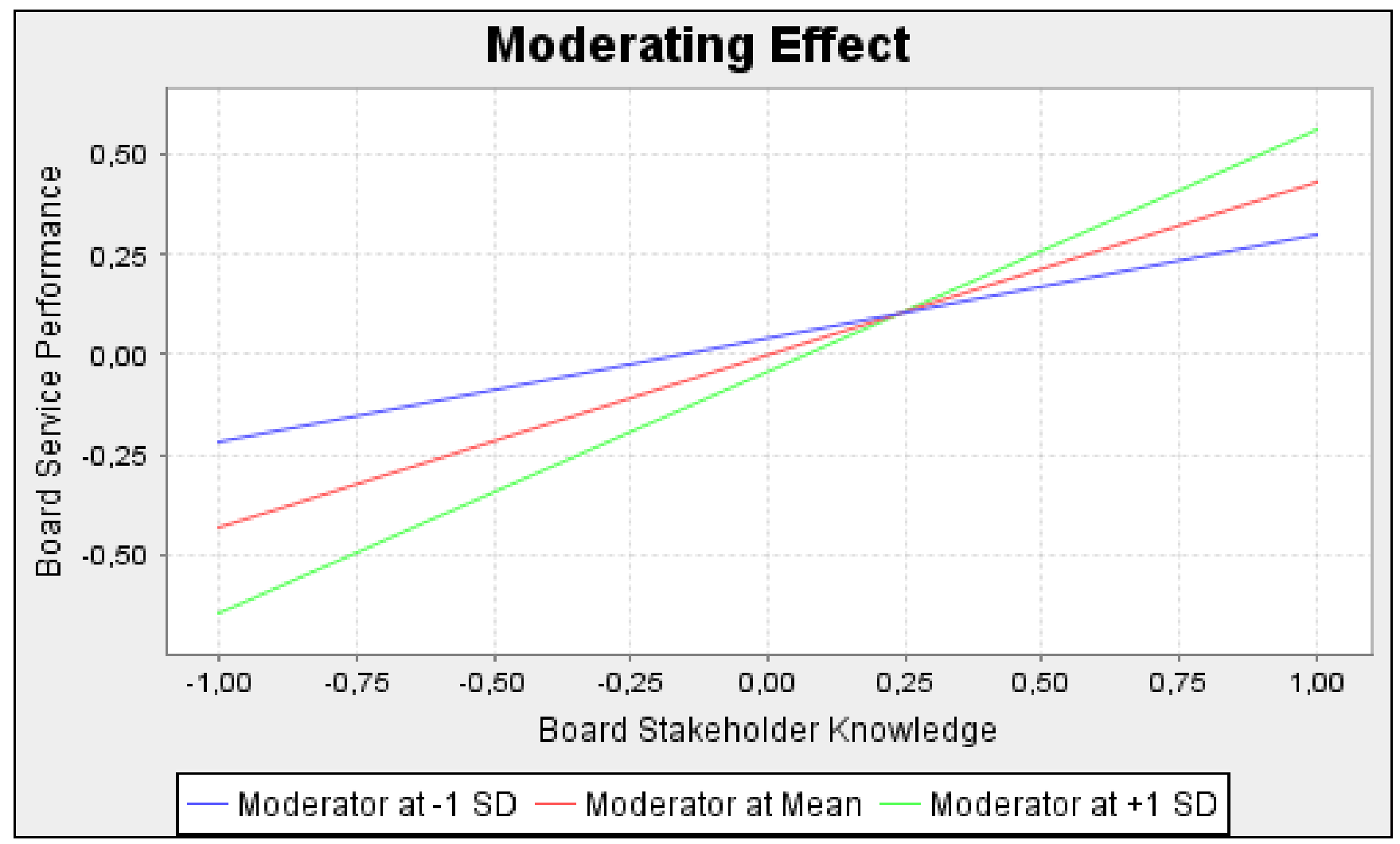

